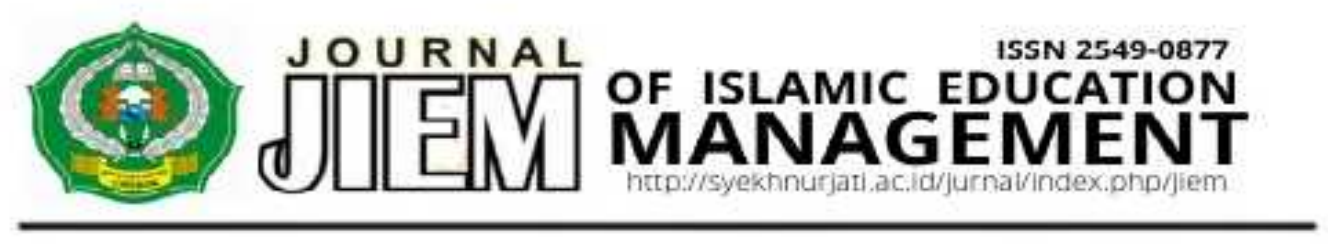

\title{
NAWACITA sebagai implementasi Kebijakan Pendidikan Nasional dalam Menyongsong Masyarakat Ekonomi Asean (MEA) \\ Zaenudin
}

Universitas Pamulang, Kab. Tanggerang Provinsi Banten

\begin{abstract}
This paper is an attempt to explain Indonesia's national education policy as stated in the Nawacita in dealing with the ASEAN Economic Community. MEA, is a process of economic integration, which aims to unite the economic potential of each ASEAN member country, so that it becomes an integrated economic area, which is seen as having a potential impact on the economy. However, these economic opportunities cannot have an impact if they are not supported by the readiness of reliable human resources. This factor is the main responsibility that must be carried out, on an ongoing basis, through quality education which is framed by the term Nawacita, to prepare competitive and highly competitive human resources. In order to realize this quality education, the Indonesian government has implemented a human resource development framework, through the direction of the national education policy, namely Nawacita. The policy is basically aimed at increasing the competitiveness of the Indonesian people, so that it has an impact on economic growth and the welfare of the nation
\end{abstract}

Keywords : MEA, Education Politics, Nawacita.

\begin{abstract}
Abstrak
Tulisan ini sebagai upaya menjelaskan, kebijakan pendidikan nasional Indonesia yang tertuang dalam Nawacita dalam mengahadapi Masyarakat Ekonomi ASEAN. MEA, merupakan proses integrasi ekonomi, yang bertujuan untuk menyatukan potensi ekonomi disetiap negara anggota ASEAN, sehingga menjadi satu kawasan ekonomi terpadu, yang dipandang memberikan dampak potensial pada bidang ekonomi. Namun peluang ekonomi tersebut, tidak dapat memberikan dampak, jika tidak didukung dengan kesiapan sumber daya manusia yang handal. Faktor inilah yang menjadi tangung jawab utama yang harus dilakukan, secara berkelanjutan, melalui pendididkan yang berkualitas yang dibingkai dengan istilah Nawacita, untuk mempersiapkan sumber daya manusia yang kompetitif, dan berdaya saing
\end{abstract}


tinggi. Demi mewujudkan pendidikan yang berkualitas tersebut, maka pemerintah Indonesia telah menerapkan kerangka pembangunan sumber daya manusia, melalui arah kebijakan pendidikan nasional, yakni Nawacita. Kebijakan tersebut pada intinya bertujuan untuk meningkatkan daya saing masyarakat Indonesia, sehingga berdampak pada pertumbuhan ekonomi dan kesejahteraan bangsa

Kata Kunci : MEA, Kebijakan Pendidikan, Nawacita

\section{A. Pendahuluan}

Masyarakat Ekonomi ASEAN (MEA), merupakan suatu sistem yang menghapus batasan wilayah, dan sekat regional kawasan. Situasi ini akan menciptakan komunitas ekonomi yang terpadu, dimana akses pasar lebih luas, dorongan mencapai efisiensi, dan daya saing ekonomi lebih tinggi, serta terbukanya peluang penyerapan tenaga kerja yang lebih besar.' Masyarakat Ekonomi ASEAN (MEA), sehingga sangat dimungkinkan menjadi alternatif ekonomi yang dapat diandalkan, dalam membangun ASEAN sebagai pusat pasar ekonomi dunia. Selain mudahnya akses ekonomi yang lahir dari integrasi pasar, ASEAN juga memiliki human capital yang besar, yakni 567,6 juta orang, (sebagai perbandingan Uni Eropa, hanya mencapai 500 juta orang), dan total Gross Domestic Product (GDP) ASEAN", berjumlah US\$T,i Triliun, ASEAN memberitan alternatif pasar yang sangat menjanjikan untuk berinvestasi (Badan Pusat Sstatistik, 2016:28).

Berbagai keungulan Masyarakat Ekonomi ASEAN (MEA) diatas, adalah potensi awal yang harus diberdayakan, untuk menjadikan potensi tersebut, sebagai peluang investasi ekonomi.
Berangkat dari deskripsi diatas, dapat dipahami bahwa, penyiapan dan pemberdayaan sumber daya manusia, memiliki peranan yang sangat signifikan terhadap peningkatan kualitas ekonomi Indonseia. Tanpa pemberdayaan terhadap sumber daya manusia yang optimal, momentum Masyarakat Ekonomi ASEAN (MEA), tidak dapat dimanfaatkan sebagai potensi, sekaligus peluang peningkatan kesejahteraan, dan kemakmuran bangsa Indonesia. Tulisan dalam artikel ini, berusaha memberikan pemetaan posisi Indonesia, dalam kancah Masyarakat Ekonomi ASEAN (MEA), serta berusaha mengkristalisasikan politk dan kebijakan pendidikan Indonesia, dalam Masyarakat Ekonomi ASEAN (MEA), sebagai momentum kebangkitan ekonomi.

\section{B. Masyarakat Ekonomi ASEAN (MEA)}

Masyarakat Ekonomi ASEAN (MEA), pada awalnya merupakan bentuk integrasi ekonomi regional, yang direncanakan untuk dicapai pada tahun 2015. Tujuan utama Masyarakat Ekonomi ASEAN (MEA), tahun 2015 ialah menjadikan ASEAN, sebagai pasar tunggal dan basis produksi, yang mana terjadi arus barang, jasa, investasi, dan tenaga terampil, secara 
terbuka dan didukung oleh aliran modal yang lebih bebas (Warta Ekspor, 4 (i), Januari 2015:4). Kesatuan pasar dan integrasi ekonomi secara terpadu, diyakini dapat memberikan manfaat yang nyata, bagi seluruh elemen masyarakat dikawasan Asia Tenggara (ASEAN).

Empat hal mendasar yang sangat potensial, dalam Masyarakat Ekonomi ASEAN (MEA), menurut Pane sebagaimana yang dikutip oleh Anung Pramudyo, (2014:94), ialah sebagai berikut: Pertama, Menuju Single market and production based, yakni arus perdagangan bebas untuk sektor barang, jasa, investasi, pekerja terampil, dan modal. Kedua, Menuju penciptaaan kawasan regional ekonomi, yang berdaya saing tinggi, dan pengembangan UKM. Ketiga, Menuju suatu kawasan dengan pembangunan ekonomi yang merata, melalui pengembangan UKM, dan program-program Initiative for ASEAN Integration (IAI). Keempat, Menuju integrasi penuh pada sektor ekonomi global.

Berdasarkan empat hal mendasar diatas, maka jaringan Masyarakat Ekonomi ASEAN (MEA), akan menciptakan pasar tunggal di wilayah ASEAN, sebagai salah satu alternatif kekuatan ekonomi, dikawasan Asia Tenggara. Pasar tunggal tersebut akan melahirkan aliran perdagangan barang, jasa, modal, dan investasi secara bebas. Indonesia sebagai anggota ASEAN yang mempunyai jumlah penduduk paling banyak, dipandang sangat berpotensi menjadi pasar yang kuat untuk perdagangan barang dan jasa, yang dihasilkan oleh negara-negara ASEAN (EDAJ, 2 (2) Mei 2013:111).

Secara konstitusinal, Pendirian Masyarakat Ekonomi ASEAN (MEA) diatur dalam Bab i, Pasal i, angka 5, dan 6, Piagam ASEAN yang berbunyi:

To create a single market and production base wich is stable, prosperous, highly competitive and economically integrated with effective facilitation for treade and investment in wich there isfreeflow ofgoods, services and investment;facilitated movement of businesspersons, profesionalitas, talents and labor, andfreer of capital and to alleviate poverty and narrow the development gap whitin ASEAN trough mutuai assistance and coopération

Berdasarkan hal tersebut diatas, maka dapat disimpulkan Masyarakat Ekonomi ASEAN (MEA), hadir tidak hanya disebabkan oleh tuntutan globalisasi, namun juga merupakan manifestasi dari cita-cita luhur para pendiri ASEAN, yang menghendaki agar kawasan ASEAN, menjadi pusat pergerakan dan pertumbuhan ekonomi, pada level pasar internasionaF. Hai ini memberikan spirit yang sangat mendasar, bahwa Masyarakat. Ekonomi ASEAN (MEA), adalah harapan kebangkitan ekonomi di kawasan regional Asia Tengara. Analisis empiris yang ditawarkan oleh Masyarakat Ekonomi Asean (MEA), terhadap potensi ekonomi yang dimilikinya, merupakan tantangan sekaligus peluang yang harus dimanfaatkan, secara serius oleh 
ASEAN untuk menunjukkan eksistesinya, sebagai kekuatan ekonomi baru di tingakat dunia. Hal ini sesungguhnya telah diwacanakan sejak tahun 1990-an, dimana kawasan Asia Tenggara (ASEAN), akan menjadi motor pengerak ekonomi dunia (Direktorat Kerjasama ASEAN, 2015:9).

Secara geopolitik ASEAN juga menjadi pusat konsentrasi dunia, sebab keberhasilanya menjaga stabilitas keamanan regicnal kawasan. ${ }^{11}$ Hal ini misalnya, ditunjukkan oleh keberhasilan penegakan demokratisasi di Myanmar, menjaga eskalasi konflik di Filipina, dan perbatasan Thailand-Kamboja, serta Kawasan Laut Cina Selatan (KLS). Stabilitas keamanan tersebut, membawa dampak pada kepercayaan dunia, untuk menjadikan kawasan Asia Tenggara (ASEAN), sebagai tujuan investasi ekonominya.

\section{Indonesia Dalam MEA}

Indonesia merupakan negara dikawasan ASEAN, dengan jumlah populasi terbanyak, dan letak geografi yang strategis, serta nilai PDB (Produk Domestik Bruto) terbesar di ASEAN, haruslah menjadi aset serta modal, agar Indonesia bisa menjadi pelaku sentral dalam AEC (ASEAN Eccnomic Community)/MEA. Masyarakat Ekonomi ASEAN (MEA), juga akan menjadi kesempatan yang baik untuk Indonesia, karena hambatan perdagangan akan cenderung berkurang, bahkan menjadi tidak ada. Hal ini akan berdampak pada peningkatan eskpor, sehingga akan meningkatkan PDB Indonesia. Di sisi lain, muncul tantangan baru bagi Indonesia, berupa permasalahan homogenitas komoditi, yang diperjualbelikan, contohnya untuk komoditas pertanian, karet, produk kayu, tekstil, dan barang elektronik.

Tantangan homogenitas

komoditi, akan berimbas pada competition risk, yang muncul karena disebabkan, banyaknya jumlah barang impor yang mengalir ke Indonesia. Ini tentu saja, akan mengancam industri lokal dalam bersaing dengan produk luar negeri, yang jauh lebih berkualitas. Hal ini pada akhirnya, akan meningkatkan defisit neraca perdagangan, bagi negara Indonesia sendiri. Upaya strategi dan persiapan yang selama ini telah dilakukan, oleh para stakeholder yang ada di Indonesia, untuk menghadapi sistem liberalisasi yang diterapkan oleh ASEAN, terutama dalam kerangka integrasi ekonomi, memang dirasakan masih kurang optimal. Namun hal tersebut, karena adanya isu-isu dalam negeri, yang butuh penanganan yang lebih intensif (Direktorat Jendral Pengembangan Ekspor Nasional dalam Warta Ekspor, 4 (i) Januari 2015:9).

Sejauh ini, langkah-langkah yang telah dilakukan oleh Indonesia, berdasarkan rencana strategis pemefihTan untuk mehghada MEA / AEC, antara lain: pertama, Penguatan daya saing ekonomi. Tanggal $27 \mathrm{Mei}$ 2011, Pemerintah meluncurkan Masterplan Percepatan dan Perluasan Pembangunan Ekonomi Indonesia. Kedua, Program ACI f Aku Cinta 
Indonesia), yang merupakan salah satu gerakan, "Nation Branding" bagian dari pengembangan desain ekonomi kreatif. Ketiga Penguatan Sektor UMKM. Keempat Perbaikan Infrastruktur. Kelima Peningkatan kualitas sumber daya manusia (SDM). Keenam Reformasi kelembagaan, dan pemerintahan, dalam rangka mendorong percepatan, pencegahan, dan pemberantasan korupsi. Upaya penindakan terhadap Tindak Pidana Korupsi (TPK), ditingkatkan melalui koordinasi, dan supervisi yang dilakukan oleh KPK, (Komisi Pemberantasan Korupsi), kepada Kejaksaan dan Kepolisian.

Menurut Wuryandani yang dikutip oleh Anung Pramudyo, (2015:95), terdapat sembilan hal mendasar yang melanda bangsa Indonesia, dalam Masyarakat Ekonomi Asean (MEA), yaitu Pertama, masih tingginya jumlah pengangguran terselubung (disguised unemployment). Kedua, rendahnya jumlah wirausahawan baru, untuk mempercepat perluasan kesempatan kerja. Ketiga, pekerja Indonesia didominasi oleh pekerja tidak terdidik, sehingga produktivitas mereka rendah. Keempat, meningkatnya jumlah pengangguran tenaga kerja terdidik, akibat ketidak sesuaian antara lulusan perguruan tinggi, dengan kebutuhan pasar tenaga kerja. Kelima, ketimpangan produktivitas tenaga kerja, antar sektor ekonomi. Keenam, sektor informal mendominasi lapangan pekerjaan. Ketujuh, pengangguran di Indonesia merupakan pengangguran tertinggi, dari 10 negara anggota ASEAN. Kedelapan, tuntutan pekerja terhadap upah minimum, tenaga kontrak, dan jaminan sosial ketenagakerjaan. Kesembilan, masalah Tenaga Kerja Indonesia (TKI) yang banyak tersebar di luar negeri. Hal ini tentunya menjadi tantangan bagi kita semua, untuk dapat memperbaiki kualitas sumber daya manusia Indonesia, agar siap bersaing dalam Masyarakat Ekonomi ASEAN (MEA). ${ }^{16}$

Esensi politik pendidikan dalam konteks negara pada dasarnya, merupakan upaya negara untuk mempengaruhi pendidikan yang dijalankannya, agar proses pendidikan tersebut, dapat menghasilkan output yang nantinya dapat dimanfaatkan, dalam rangka mewujudkan tujuan dari negara itu sendiri. Hal ini sejalan dengan pendapat H.A.R. Tilaar dan Riant Nugroho, (2009:260) yang menyatakan bahwa, pendidikan merupakan bagain dari kebijakan publik, sehingga meniscayakan perlunya peran negara untuk hadir, dalam rangka mengatur kebijakan tersebut, agar memberikan dampak yang positif kepada setiap warga negara (publik), sebagai pemegang kedaulatan tertinggi dalam negara. Kehadiran negara untuk mengatur pendidikan dalam bentuk kebijakan, sangat ditentukan oleh ideologi (pandangan hidup) yang diemban oleh negara tersebut. Faktor inilah yang menentukan karakter, dan tipologi masyarakat yang dibentuknya. Dengan demikian, politik pendidikan dapat dipahami sebagai strategi pendidikan yang dirancang negara, 
dalam upaya menciptakan kualitas human resources (sumberdaya manusia) yang dicita-citakan, berdasarkan ideologi yang menjadi dasar kepribadian bangsa tersebut.

Peran penting ideologi dalam politik, sebagai suatu identitas kekuasaan, berangkat dari adanya presepsi yang sama, mengenai tujuan yang hendak dicapai.

Adanya persamaan tersebut, dipicu oleh kesamaan ideologi yang sangat mendasar dari setiap inidvidu dalam suatu kelompok sosial. Kesamaan ideologi dalam kelompok sosial tersebut, akan melahirkan komitmen bersama (kontrak sosial), yang melahirkan sistem politik, sebagai alat kekuasaan untuk menjalankan kontrak sosial tersebut. Dalam menjalakan kekuasaan, politik melahirkan kebijakan, sebagai upaya untuk mengarahkan setiap individu, dalam kelompok sosial, agar terarah sesuai dengan tujuan dalam kontrak sosial, yang telah disepakati sebelumnya. Sehingganya secara sederhana, dapat dipahami bahwa setiap keputusan politik, selalu memiliki dampak yang sangat signifikan, dalam mempengaruhi kebijakan-kebijakan publik, yang menyangkut hak setiap individu, dari kelompok sosial itu sendiri. Jika kelompok sosial tersebut, dimaknai sebagai negara, maka sistem politik yang dianut oleh negara tersebut, akan memberikan pengaruh yang sangat kuat, terhadap kebijakan pendidikan dalam negara tersebut.

Kuatnya pengaruh politik pendidikan, dalam mengatur kebijakan-kebijakan pendidikan, dapat dipahami melalui empat hal yang ditegaskan oleh Sunarso, mengenai makna penting politik pendidikan. Pertama, politik pendidikan ialah metode yang digunakan untuk mempengaruhi pihak lain, untuk mencapai tujuan pendidikan. Kedua, politik pendidikan lebih beroreantasi, pada bagaimana tujuan pendidikan dapat dicapai. Ketiga, politik pendidikan berbicara mengenai metode, untuk mencapai tujuan pendidikan. Keempat, politik pendidikan berbicara mengenai sejauhmana, pancapaian pendidikan sebagai pembentuk manusia yang berkualitas, penyangga ekonomi nasional, pembentuk bangsa yang berkarakter.

Keempat makna mendasar mengenai politik pendidikan diatas, menunjukkan bahwa, politik pendidikan memiliki fungsi yang sangat penting dalam kehidupan bernegara, sebab melalui politik pendidikanlah arah kebijakan pendidikan nasional dapat dirancang, sesuai dengan ideologi dan kepentingan nasional dari negara itu sendiri. Melalui upaya tersebut, diharapkan dapat melahirkan konsep pendidikan yang jelas, tepat, kuat, dan kokoh, sehingga dapat melahirkan output pendidikan yang berkualitas, dan juga memiliki mentalitas kepribadian, yang sesuai dengan karakter bangsa itu sendiri (Ahmad Zain Sarnoto dalam Jurnal Educhild, 1 (1) 2012) 


\section{Falsafah Pancasila Sebagai Basic Ideologi Politik Pendidikan Nasional}

Keterkaitan antara pendidikan dan politik pada tataran empiris, pada akhirnya akan berdampak pada wilayah filosofis. Hal ini misalnya, terlihat dari karakter filsafat pendidikan disuatu negara, yang seringkali merupakan refleksi terhadap prinsip-prinsip ideologis yang diadopsi oleh negara tersebut (M. Sirozi, 2005:12). Di Indonesia sendiri, Pancasila merupakan ideologi dan Undang-Undang Dasar 1945 (UUD 45) merupakan konstitusi, sehingga politik pendidikannyapun secara ideal, harus berpijak pada Pancasila (sebagai landasan ideologis), dan UUD 45 (sebagai landasan yuridis). Hal ini menunjukkan, ideologi pendidikan di Indonesia, berangkat dari semangat Pancasila, sebagai dasar filosofis negara, yang kemudian berkembang menjadi ideologi yang melatar belakangi, politik pendidikan nasionalnya. Kenyataan tersebut, telah dijelaskan oleh William F. O'Neil, (2008:125), yang mendeskripsikan pola hubungan antara wilayah etika, dan filosofi politik pada satu sisi, dengan wilayah ideologi pendidikan disisi yang lain. Melalui pola yang dideskripsikan oleh William F. O'Neil tersebut, paling tidak terdapat tiga pola keterkaitan yang membentuk hubungan, antara wilayah filosofis, dengan wilayah pendidikan, yaitu: keterkaitan logis, keterkaitan psikologis, dan keterkaitan sosial.

Pengaruh ideologi negara dalam bidang pendidikan, sebagai basic values politik pendidikan nasional, telah dijelaskan dalam teori valuational, yang dikembangkan oleh Thomas P. Jenkin. Menurut Thomas P. Jenkin, setiap kebijakan negara yang diputuskan, termasuk dalam bidang pendidikan, selalu memiliki keterkaitan yang erat dengan ideologi politik yang dominan pada negara tersebut. Artinya, setiap kebijakan yang dihasilkan (misalnya dalam bidang pendidikan), memiliki hubungan dengan ideologi politik yang melatarbelakangi pembuatan kebijakan tersebut. Hal ini misalnya, dapat dicontohkan bila suatu negara memilki kecenderungan ideologi yang nasionalis, maka format kebijakan yang dihasilkan, akan sesuai dan relevan dengan aliran ideologi yang bercorak nasionalis (Hamlan, dalam Jurnal Hunafa, 10 (1) Juni 2013:179). Berdasarkan teori valuational di atas, maka dapat dipahami bahwa, ideologi politik pendidikan nasional, didasarkan pada Pancasila sebagai dasar falsafah negara. Hal ini merupakan konsekuensi logis, bagi setiap warga negara, yang telah menyepakati Pancasila sebagai core values, dalam kehidupan berbangsa dan bernegara. Sehingga segala hal yang menyangkut kebutuhan bersama, dalam konteks bernegara termasuk bidang pendidikan, harus dilakukan dengan semangat Pancasila, sebagai simbol kesepakatan bersama, yang mengikat semua pihak, demi kepentingan nasional.

Asumsi mengenai Pancasila sebagai dasar politik pendidikan nasional, dipertegas oleh Surajiyo, 
(2014:111), yang menyatakan bahwa, Pancasila sebagai dasar negara pada hakikatnya, merupakan sumber dari segala norma, baik norma hukum, norma moral, maupun norma kenegaraan lainnya. Norma hukum adalah suatu sistem peraturan perundang-undangan, yang berlaku di Indonesia. Dalam pengertian inilah maka Pancasila, berkedudukan sebagai sumber dari segala sumber hukum di negara Indonesia. Eksistestensi Pancasila dalam kehidupan bernegara, juga diterima sebagai karakter bangsa, hal ini tertuang dalam Ketetapan MPR No. VI/MPR/2001, tentang etika kehidupan berbangsa, yang menyatakan bahwa, pengertian etika politik dalam kehidupan berbangsa, merupakan rumusan yang bersumber dari ajaran agama, khususnya yang bersifat universal, dan nilai luhur budaya bangsa, yang tercermin dalam Pancasila sebagai acuan dasar dalam berpikir, bersikap, dan bertingkah laku, dalam kehidupan berbangsa.

Pancasila sebagai dasar falsafah negara, tidak hanya merupakan sumber bagi peraturan perundangundangan, melainkan juga merupakan sumber moralitas, terutama dalam hubungannya dengan legitimasi kekuasaan, hukum, serta berbagai kebijakan dalam pelaksanaan, dan penyelenggaraan negara. Hal ini memberi ketegasan, bahwa konsep pendidikan yang dibudayakan secara formal, dalam konteks pendidikan nasional, merupakan konsep pendidikan yang mengacu, kepada nilai-nilai luhur Pancasila.
Menurut Ambiro Puji Asmaroini, (2017:63), Pembudayaan nilai-nilai luhur Pancasila, perlu diupayakan dengan harapan, akan lahir penghayatan dan pengalaman nilai-nilai luhur Pancasila, di berbagai bidang kehidupan bagi seluruh masyarakat Indonesia. Dengan demikian, maka dapat disimpulkan, politik pendidikan nasional yang diterapkan di Indonesia, merupakan sistem politik pancasila. Nilai-nilai luhur Pancasila, menjadi kerangka pengembangan pendidikan nasional, termasuk dalam mendesain format kebijakan pendidikan, yang tentunya disesuaikan dengan kenyataan, dan tantangan yang dihadapi oleh bangsa Indonesia, yang selalu mengalami perubahan secara dinamis, dari waktu ke waktu. Termasuk dalam menghadapi tantangan Masyarakat Ekonomi ASEAN (MEA), yang sangat kompetitif.

\section{E. Nawacita Sebagai Arah Kebijakan Pendidikan Nasional dalam Masyarakat Ekonomi ASEAN (MEA)}

Indikator masyarakat modern, secara umum dapat dicermati melalui proses perumusan kebijakan pendidikan. Hal ini, berangkat dari adanya kesadaran dalam masyarakat modern, bahwa pendidikan berada pada wilayah publik, yang tentunya perlu diatur oleh pemerintah, sebagai pemegang otoritas kekuasaan dalam negara. Esensi pendidikan yang masuk dalam wilayah publik, akan menyebabkan pendidikan menjadi bersifat politis, karena dikontrol oleh 
pemerintah. Karena kuatnya kaitan antara masalah pendidikan dan politik, serta aspek-aspek publik lainnya, maka setiap kebijakan pemerintah di bidang pendidikan, pada umumnya merefleksikan pandangannya, tentang masyarakat dan keyakinan politiknya. Dalam konteks pemerintahan, selalu saja pemerintah menempatkan perioritas kebijakan pendidikan, atas dasar dasar pertimbangan politik, daiam menghadapi berbagai tantangan zaman yang sealu berubah dan berkembang (Sunarsono dalam Jurnal Civics, 4 (2) 2007:31).

Hadirnya Masyarakat Ekonomi ASEAN (MEA), yang telah diresmikan pada tanggal 31 Desember 2015, merupakan salah satu tantangan yang harus disikapi secara serius oleh pemerintah, disegala bidang sosial kemasyarakatan, tanpa terkecuali dalam bidang pendidikan. Sehingganya untuk menjawab tantangan tersebut, Pemerintah Republik Indonesia, dibawah kepemimpinan Joko Widodo dan Jusuf Kalla, telah merancang sembilan prioritas pembangunan, yang diberi nama Nawacita. Sembilan prioritas pembagunan tersebut meliputi. Pertama, menghadirkan kembali negara untuk melindungi segenap bangsa, dan memberikan rasa aman pada seluruh warga negara. Kedua, membuat pemerintah tidak absen, dengan membangun tata kelola pemerintahan, yang bersih, efektif, demokratis, dan terpei caya. Ketiga, menolak negara lemah, dengan melakukan reformasi sistem, dan penegakan hukum yang bebas korupsi, bermartabat, dan terpercaya. Keempat, mewujudkan kemandirian ekonomi, dengan menggerakkan sektor strategis ekonomi domestik. Kelima, membangun Indonesia dari pinggiran. Keenam, meningkatkan produktivitas rakyat, dan daya saing. Ketujuh, meningkatkan kualitas hidup manusia Indonesia, melalui peningkatan kualitas pendidikan, dan pelatihan. Kedelapan, melakukan revolusi karakter bangsa, melalui kebijakan penataan kembali kurikulum pendidikan nasional. Kesembilan, memperteguh kebhinnekaan, dan memperkuat restorasi sosial Indonesia (Mochdar Soleman dan Mohammad Noer dalam Jurnal Politik 13 (1) 2017 :4).

Kesembilan perioritas pembangunan tersebut, merupakan kebijakan pemerintah yang diberi nama Nawacita. Secara etimologi, Nawacita berasal dari bahasa sansekerta, yakni Nawa yang berarti sembilan, dan Cita yang berarti harapan. Dalam konteks perpolitikan di Indonesia, Nawacita merupakan sebutan yang merujuk pada sembilan program prioritas, yang digagas oleh pasangan Joko Widodo dan Jusuf Kalla, dalam pemilihan Presiden tahun 2014 silam. Adapun Secara historis, Nawacita sesungguhnya merupakan implementasi dari Trisakti Bung Karno, yang bersumber dari saripati Pancasila sebagai cerminan kepribadian bangsa. Sebagai prioritas pembangunan, Nawacita menjadi kerangka kebijakan pembangunan yang menjadi acuan pemerintah, dalam merancang program 
pembangunannya, termasuk dalam bidang pendidikan. Hal ini, terlihat dari desain kebijakan pendidikan, yang tertuang dalam RPJMN (Rencana Pembangunan Jangka Menenggah Nasional), yang disusun secara komprehensif, dalam rangka meningkatkan kualitas daya saing masyarakat Indonesia, di kancah ekonomi global, dan secara khusus dalam Masyarakat Ekonomi ASEAN (MEA).

Desain Kebijakan pendidikan nasional Indonesia, pada dasarnya telah tertuang secara utuh dalam RPJMN (Rencana Pembangunan Jangka Menenggah Nasional) 20152019, temasuk dalam menjawab tantangan Masyarakat Ekonomi ASEAN (MEA), yang telah dirintis sejak tanggal 31 Desember 2015, adapun kerangka dasar dalam RPJMN 2015-2019, ialah mewujudkan Indonesia yang berdaulat, mandiri, dan berkepribadian berlandaskan gotongroyong. Dalam bidang pendidikan, kebijakan pemerintah telah tertuang dalam, rencana strategis Kementerian Pendidikan dan Kebudayaan, (Kemendikbud) tahun 2015-2019.

Arah kebijakan dan strategi Kementerian Pendidikan dan Kebudayaan, (Kemendikbud) tahun 2015-2019, memuat langkah-langkah yang berupa program indikatif, untuk memecahkan permasalahan yang penting, dan mendesak untuk segera dilaksanakan, serta memiliki dampak yang besar terhadap pencapaian visi, misi, tujuan, serta sasaran strategis, Kemendikbud pada periode yang bersangkutan. Arah kebijakan dan strategi Kemendikbud, juga disusun dengan sangat memperhatikan, hasil capaian pembangunan pendidikan dan kebudayaan, sampai tahun 2014. Adapun Pertimbangan lain ialah segala hasil studi, penelitian, masukan pemangku kepentingan, dan aspirasi masyarakat. Termasuk di dalamnya, ialah prediksi kondisi, dan lingkungan di masa depan. Oleh karenanya, fokus kebijakan dalam periode 2015-2019, didasarkan pada percepatan peningkatan mutu, dan akses untuk menghadapi persaingan global, dengan pemahaman akan keberagaman, penguatan praktik, dan inovasi.

Arah kebijakan pendidikan nasional, merupakan penjabaran urusan pemerintahan, dan/atau prioritas pembangunan, sesuai dengan visi dan misi Presiden, selaku kepala negara dan kepala pemerintahan, yang rumusannya mencerminkan bidang urusan pemerintahan, yang menjadi tanggungjawab Kemendikbud, sebagai sentral katalisator pendidikan nasional. Arah pembagunan nasional, tertuang dalam 9 rencana strategis pembangunan nasional, yang disebut dengan Nawacita, adapun dalam pembanguan pendidikan dalam skala nasional, khususnya yang sesuai dengan tugas dan fungsi Kemendikbud, tertuang dalam Nawacita nomor 5, 6, 8, 9, dan 2. Khusus agenda pembangunan pendidikan, dibahas dalam Nawacita nomor 5, 6, dan 8. Pembangunan kebudayaan, dibahas dalam Nawacita nomor 8 dan 9, sedangkan penguatan efektivitas reformasi birokrasi dan tata 
kelola, terdapat dalam Nawacita nomor 2. Program Nawacita pada butir $5,6,8,9$, dan 2 tersebut, merupakan upaya strategis pemerintah, untuk meningkatkan kualitas sumberdaya manusia, sehingga dapat bersaing dengan negara lain, baik dalam kancah Masyarakat Ekonomi ASEAN (MEA), maupun dalam skala yang lebih luas lagi.

Adapun penjabaran dari konsep Nawacita diatas, yang menjadi orieantasi arah kebijakan pendidikan nasional, ialah sebagai berikut: Pertama, Nawacita 5: meningkatkan kualitas hidup manusia dan masyarakat Indonesia, (bidang pendidikan). Kebijakan pendidikan diarahkan pada aspek pemudahan akses, untuk mendapatkan pendidikan serta penguatan kualitas siswa, guru, orang tua, dan aparatur pendidikan, yang terlibat dalam proses pendidikan tersebut. Selain itu pada poin nawacita ini, seluruh desain pendidikan, diarahkan pada penguatan karakter, dan peningkatan sistem mutu. Contohnya: Kurikulum 2013, Pendidikan Wajib Belajar 19 Tahun, dan Forum KKG (Kelompok Kerja Guru), Guru 3T, dan BOS, KIP, dan KKNI.

Kedua, Nawacita 6: meningkatkan produktivitas rakyat dan daya saing di pasar internasional, (bidang pendidikan). Kebijakan Pendidikan diarahkan untuk membentuk live skill, dan pemberdayaan potensi lokal disetiap daerah, sehingga dapat memunculkan values local yang kompetitif. Perwuudan dari arah kebijakan

pendidikan ini, ditunjukkan dengan dibukanya, Sekolah Menengah Kejuaran (SMK), yang dikonsentrasikan pada komuditas unggulan pada masing-masing daerah, sehingga dengan kebijakan ini, diharapkan dunia pendidikan dapat menyiapkan human capital, yang cukup untuk mengelola aset, pada setiap daerah masing-masing secara mandiri.

Ketiga, Nawacita 8: melakukan revolusi karakter bangsa, (bidang pendidikan dan kebudayaan) Kebijakan pendidikan diarahkan untuk, melakukan upaya revolusi mental secara kelembagaan, melalui institusi pendidikan, yang diwujudkan melalui pendidikan karakter, yang diintegralkan pada pelajaran Pendidikan Agama, dan Kewarganegaraan. Kebijakan pendidikan pada bidang ini, diharapkan dapat melahirkan individuindividu baru, yang berwawasan luas, dengan mentalitas moral yang baik. Melalui kebijakan ini, pemerintah berupaya mengali karakter luhur bangsa Indonesia, untuk melahirkan nilai kepribadian, yang memiliki semagat nasionalisme, dan patriotisme sebagai bangsa Indonesia.

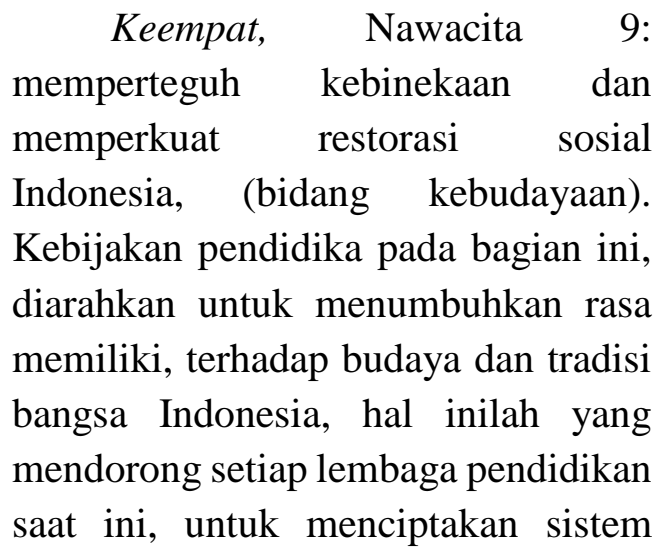


pendidikan, yang memberikan ruang yang cukup pada kebudayaan, disetiap daerah tertentu, untuk dimasukkan ke dalam proses pembelajaran. Situasi tersebut lahir dari adanya kesadaran yang mendalam, bahwa pendidikan harus menyelamatkan budaya, sebagai warisan kebangsaan. Selain itu melalui nawacita ke-9 ini, pemerintah memiliki peluang yang sangat luas, untuk menciptakan pendidikan yang representatif, dengan bahasa pengantar bahasa Indonesia, sebagai prasayarat stabilitas kebhinekaan, dalam konteks kenegaraan. Sehingga pendidikan dapat menjadi momentum yang mempersatukan, dan bukan sebaliknya.

Kelima, Nawacita 2: membangun tata kelola pemerintahan yang bersih, efektif, dan terpercaya (pengelolaan kelembagaan). Kebijakan pendidikan diarahkan untuk menciptakan lembaga pendidikan yang bersih, serta pengelolaan pendidikan yang transpran, efektif, dan efisien, sehingga memberikan daya dukung bagi keberhasilan proses pendidikan. Melalui tahapan ini, kebijakan pendidikan dirumuskan untuk mendesaian pendidikan yang teratur, dan tersistematis, sehingga memberikan kepercayaan dan dukungan penuh dari publik. Perumusan kebijakan pendidikan pada poin ini, dapat diejawantahkan dalam bentuk (misalnya) e-goverment, Unit layanan Terpadu (ULT), dan reformasi lembaga.

Jika dicermati secara mendalam, maka arah kebijakan pendidikan nasional, terkait dengan Masyarakat
Ekonomi ASEAN (MEA), didesain untuk melakukan perubahan paradigma, dalam mempresepsikan pemanfaatan sumber daya ekonomi. Dari perspektif eksploitasi bahan mentah, dengan kualitas iptek yang sangat rendah, menjadi negara dengan tingkat perspektif ekonomi yang tinggi, dan konsep pengelolaan ekonomi yang moderen, dan berkelanjutan. Hal ini akan membentuk kualitas sumber daya manusia yang kompetitif, sehingga dapat meningkatkan daya saing, di internal Masyarakat Ekonomi ASEAN (MEA).

\section{F. Kesimpulan}

Masyarakat Ekonomi ASEAN (MEA), merupakan bentuk kesepakatan dan kesepahaman bersama, dari negara-negara anggota ASEAN, untuk menyatukan potensi, dan peluang ekonomi di kawasan Asia Tenggara. Upaya tersebut menjadikan ASEAN tampil sebagai alternatif kekuatan ekonomi baru di dunia. Sehingga sebagai negara anggota dalam komuniatas tersebut, Indonesia memiliki peluang yang sangat menjanjikan, untuk memanfaatkannya menjadi peluang kebangkitan ekonomi, hal ini didukung selain oleh sumber daya alam yang melimpah, namun juga oleh potensi human capital yang dimiliki bangsa Indonesia, sebagai negara dengan jumlah penduduk terbesar di ASEAN. Namun potensi tersebut, haruslah dikelola secara efektif, dan efisien, sehingga dapat memberikan dampak yang signifikan, dan bukan sebaliknya 
menjadi faktor penghambat pertumbuhan ekonomi.

Pengelolaan sumberdaya manusia Indonesia sangatlah penting, sebab sumber daya manusia adalah aset utama, dalam pembangunan bangsa dan ekonomi. Hal inilah yang menjadi arah kebijakan pendidikan Nasional, yang tertuang dalam rencana strategis (Renstra) Kementerian Pendidikan dan Kebudayaan, melalui penjabaran program Nawacita pada butir $5,6,8,9$, dan 2 , yang secara umum bertujuan untuk, menghasilkan kualitas sumberdaya manusia yang cerdas, terampil, dan berkarakter. Sumberdaya manusia inilah yang diharapkan dapat mengantarkan Indonesia, menjadi negara yang berdaulat secara politik, berdikari secara ekonomi, dan berkepribaian dalam kebudayaan. Sehingga dapat bersaing dalam era global, dan khususnya dalam kancah Masyarakat Ekonomi ASEAN (MEA).

\section{G. Daftar Pustaka}

Abidin, Zainal, "Peluang dan Tantangan MEA: Peluang dan Kerjasama di KawasanASEAN", Ri'ayah, 1 (1) Januari-Juni 2016: 34.

Ambiro Puji Asmaroini, "Menjaga Eksistensi Pancasila dan Penerapannya Bagi Masyarakat di Era Globalisasi, Jurnal Pancasila dan

Kewarganegaraan, 1 (2) Januari 2017: 63.

Direktorat Jenderal Pengembangan Ekspor Nasional, "Peluang dan Tantangan Indonesia Dalam
Pasar Bebas Asean," Warta Ekspor, 4 (1) Januari 2015: 3.

Direktorat Jenderal Pengembangan Ekspor Nasional, "Peluang yang Dihadapi oleh Indonesia Dalam Menghadapi MEA 2015," Warta Ekspor, 4 (1) Januari 2015:4.

Direktorat Jenderal Pengembangan Ekspor Nasional, "Strategi Menghadapi MEA 2015, Warta Ekspor, 4 (1) Januari 2015: 9.

Direktorat Kerjasama ASEAN, "MEA dan Dinamika Ekonomi Tiongkok, India, dan Dunia", Masyarakat ASEAN,

Desember 2015: 9.

Direktorat Kerjasama Ekonomi ASEAN, "Bukan AFTA 2015", Masyarakat ASEAN, Maret 2017:10.

Direktorat Politik dan Keamanan ASEAN, "Perdamaian Dan Stabilitas Keamanan:Conditio Sine Qua Non' Bagi Masyarakat Asean", Masyarakat ASEAN, (10) Desember 2015: 8.

Hamlan, "Politik Pendidikan Islam

Dalam Konfigurasi Sistem Pendidikan Di Indoensia", Jurnal Hunafa, 10 (1) Juni 2013:179.

Kementerian Pendidikan dan Kebudayaan, Rencana Strategis

Kementerian Pendidikan dan Kebudayaan 2015-2019, Jakarta: Kementerian Penddidikan dan Kebudayaan, 2015) him 54.

Pramudyo Anung "Mempersiapkan

Sumber Daya Manusia

Indonesia Dalam Menghadapi Masyarakat Ekonomi ASEAN 
Tahun 2015", JBMA, 2 (2)

September 2014: 94

Syukriah, Ana dan Imam Hamdani,

"Peningkatan Eksistensi

UMKM Melalui Comparative

Advantage Dalam Rangka

Menghadapi MEA 2015 di

Temangung", Economics

Development Analysis Journal,

2 (2) Mei 2013:111.

Mochdar Soleman dan Mohammad

Noer, "Nawacita Sebagai

Strategi Khusus Jokowi Periode

Oktober 2014 - 20 Oktober

2015", Jurnal Politik, 13 (1)

Tahun 2017: 4.

O'Neil William F. Ideologi-ideologi

Pendidikan, Yogyakarta:

Pustaka Pelajar, 2008.

PH Slamet, "Politik Pendidikan Indonesia Dalam Abad Ke-21", Jurnal Cakrawala Pendidikan, 33 (3), Oktober 2014: 327.

Saragih Mujahid Widian, "Relevansi

Konsep Trisakti Bung Soekarno

Dengan Nawacita Pemerintahan

Jokowi-Jk", Skripsi, Fakultas
Ilmu Sosial Dan Ilmu Politik, Universitas Sumatera Utara, 2015, him 68 .

Sarnoto Ahmad Zain, "Konsepsi Politik Pendidikan Di Indonesia", Jurnal Educhild,1 (1) 2012

Sirozi M. Politik Pendidikan:

Dinamika Hubungan Antara

Kepentingan Kekuasaan dan

Praktik Penyelenggaraan

Pendidikan. Jakarta: PT

RajaGrafindo Persada, 2005.

Sunarsono, "Pendidikan Politik dan

Politik Pendidikan", Jurnal

Civics, 4 (2) 2007

Surajiyo, "Pancasila Sebagai Etika

Politik di Indonesia", Jurnal

Ultima Humaniora, 2

Maret 2014:

Tilaar H-A.R dan Riant Nugroho. Kebijakan Pendidikan:

Pengantar Untuk Memahami

Kebijakan Pendidikan dan Kebijakan Pendidikan Sebagai Kebijakan Publik, Yogyakarta: Pustaka Pelajar, 2009. 